\title{
COMPARISON LEATHER PROPERTIES OF BARKI AND ABU-DLEEK SHEEPS
}

\author{
A.I. Nasr' ; M.M. Abdelsalam and A.H. Azzam ${ }^{1}$ \\ ${ }^{I}$ Department of Wool Production and Technology, Desert Research Center, Cairo, Egypt. \\ ${ }^{2}$ Animal Production Department, Faculty of Agriculture, Alexandria University, Egypt.
}

(Received 4/5/2016, Accepted 2/3/ 2017)

\section{SUMMARY}

\begin{abstract}
The aim followed in the present paper was to evaluate physical and chemical properties of Barki and AbuDleek sheep leathers, tanned with different tanning materials. Fifteen sheepskins from each breed at marketing age were collected and tanned with different tanning methods; mineral with chromium salts and vegetable with quebracho or mimosa extracts. Leather properties were assessed. Abu-Dleek leathers were higher quality than Barki leathers when tanned with different tanning materials. With respect to influence of tanning method, mineral tanned leathers were higher quality than vegetable tanned leathers. Within vegetable tanned leathers, leathers tanned with quebracho extract were higher than leathers tanned with mimosa extract.
\end{abstract}

Keyword: Sheep, tanning, chrome, vegetable, leathers.

\section{INTRODUCTION}

Sheep are considered from the most important livestock in Egyptian arid and semi-arid regions. According to FAO (2013), there are about 5.5 million sheep heads in Egypt; produced 4.7 million pieces of skin weighed 7.146 tones (fresh weight). There are about 702,213 heads of Barki breed located in the North Western Coastal Zone (Younis, 1995) and about 137,357 heads belong to Abu-Dleek breed in El-ShalateenHalaib triangle region (Azzam, 2003).

Although sheep skins are important resources that could contribute a significant income to pastoralists, they are not completely manufactured in Egypt due to two constrains. Firstly sheep are mostly slaughtered by Bedouin in desert areas outside slaughterhouses, which makes it difficult to collect the skins. Secondly, the long distance between desert areas and tanneries increases the transportation costs. In Egypt nowadays, the leather production process comprises collecting the skins or hides from slaughterhouses, preserving them with salt then transporting them to the tanneries. Most tanneries are located in Cairo or Alexandria and relied mainly on the chrome tanning method (Nasr, 2011).

Leather tanning and finishing methods are developed to produce different types of leathers, which can be used in different uses such as garments, footwear, luggage and upholstery (BASF, 2007).

Although, the future of tanning industry lies with chromium salts (Anthony, 1998), it is most common source of metal pollutants in the environment by discharging tannery wasted directly into sewage system (Chakir, 2001).

Thus, the present investigation aimed to use vegetable tanning materials as a non-pollutant material instead of chromium salts. In addition, to study the effect of tanning methods and materials on physical and chemical properties of the lowest sheep breeds leathers exploitation in Egyptian desert areas; Barki and AbuDleek sheep leathers.

\section{MATERIALS AND METHODS}

Fifteen fresh male sheep skins were collected at marketing age (aged $12-18$ months) from each breed. Barki and Abu-Dleek sheep skins were collected from Mariout research station and Shalateen research 
station, respectively. All skins were preserved with salt then transported to Kalash tannery at El-Max region in Alexandria city and prepared to tanning with different methods.

Two tanning methods with three materials were used in this study, the first method was mineral tanning by using chrome and the second method was the vegetable tanning using quebracho or mimosa powder extract.

Tanning process is continuously steps, started with beamhouse steps (soaking, unhairing, reliming, deliming, bating, pickling) followed with tanning step (by chrome, quebracho or mimosa), then finishing steps. All skins were common in the beamhouse processes from soaking to pickling step, but differed after that in tanning and finishing steps.

Samples for various physical and chemical tests from all leathers were obtained as per Egyptian Standard (E.S.122) and (E.S.123), respectively. Specimens were conditioned at $20^{\circ} \mathrm{C} \pm 2{ }^{\circ} \mathrm{C}$ and $65 \% \pm 4 \%$ R.H. over a period of $48 \mathrm{hrs}$. Physical properties such as tensile strength, percentage elongation at break split tear strength, bursting strength, permeability to water vapor, static water absorption and were measured as per standard procedures. Each value reported is an average of four samples ( 2 values along the backbone and 2 values across the back bone). Chemical properties such as moisture, total ash content, oils and fats and $\mathrm{pH}$ have been carried out for all leathers according to standard procedures.

Data were analyzed using GLM of SAS (2008) to evaluate the differences among produced leathers with different tanning methods or materials. Significant differences were detected using the Duncan Multiple Range Test. The fixed effects model was as follow:

$Y_{i j k}=\mu+R_{i}+T_{j}+R T_{i j}+e_{i j k}$

Where:

$Y_{i j}=$ The observation taken on the $\mathrm{j}^{\text {th }}$ leather;

$\mu=$ Overall mean;

$R_{i}=$ a fixed effect of the $\mathrm{i}^{\text {th }}$ breed (Barki and Abu-Dleek).

$T_{j}=$ a fixed effect of the $\mathrm{j}^{\text {th }}$ tanning methods (mineral and vegetable) or tanning materials (chrome, quebracho and mimosa)

$R T_{i j}=$ interaction between breed and tanning methods or tanning materials.

$e_{i j}=$ random error assumed to be normally distributed with mean $=0$ and variance $=\sigma^{2}$

\section{RESULTS AND DISCUSSIONS}

Results of physical and chemical properties measured on produced leathers are displayed in Tables (1) and (2).

\section{Physical properties}

\section{Breed effect}

Results obtained showed that Abu-Dleek leathers seemed to be of higher quality. Abu-Dleek leathers were significantly higher in tensile strength $\left(193.32 \mathrm{~kg} / \mathrm{cm}^{2}\right)$, permeability to water vapor (424.17 $\mathrm{mg} / \mathrm{mm}^{2} / \mathrm{hr}$ ) and lower water absorption (190.48 and 219.10\%) than those of Barki leathers. Also, tearing strength $(45.61 \mathrm{~kg} / \mathrm{cm})$ and elongation $(60.49 \%)$ were insignificant higher values in Abu-Dleek leathers than Barki leathers.

Review reveals that Barki sheepskins had more follicle density and produced wool fibers in lower thickness than that produced from Abu-Dleek sheepskins, which considered hair fibers such as in goat (Kotb, 1987, Abdelsalam and Haider, 1995 and Azzam, 2003).

On the other hand, Jackson-Mass and Snyman (2000) found the same trends between leathers of African sheep breeds, which were higher quality in sheep breed produced hair fibers than those produced wool fibers. 
Table (1): Least square means \pm SEM of physical and chemical properties of tanned leathers as affected by breed, tanning method and tanning material.

\begin{tabular}{|c|c|c|c|c|c|c|c|c|c|c|c|}
\hline \multirow[t]{2}{*}{ Item } & \multicolumn{3}{|c|}{ Breed } & \multicolumn{3}{|c|}{ Method } & \multicolumn{4}{|c|}{ Material } & \multirow[b]{2}{*}{ SEM } \\
\hline & Barki & $\begin{array}{l}\text { Abu- } \\
\text { Dleek }\end{array}$ & Sig. & Mineral & Vegetable & $\begin{array}{l}\mathrm{Si} \\
\text { g. }\end{array}$ & Chrome & Quebracho & Mimosa & Sig. & \\
\hline $\mathrm{N}$ & 15 & 15 & -- & 10 & 20 & -- & 10 & 10 & 10 & -- & \\
\hline \multicolumn{12}{|l|}{ Physical properties } \\
\hline Weight $(\mathrm{kg})$ & 0.306 & 0.337 & NS & $0.279^{\mathrm{b}}$ & $0.343^{\mathrm{a}}$ & $*$ & $0.279^{\mathrm{b}}$ & $0.312^{\mathrm{b}}$ & $0.373^{\mathrm{a}}$ & $*$ & 0.013 \\
\hline Thickness (mm) & 1.30 & 1.11 & NS & $0.83^{\mathrm{b}}$ & $1.39^{\mathrm{a}}$ & $* *$ & $0.83^{\mathrm{b}}$ & $1.31^{\mathrm{a}}$ & $1.48^{\mathrm{a}}$ & $* *$ & 0.06 \\
\hline Tensile $\left(\mathrm{kg} / \mathrm{cm}^{2}\right)$ & $146.15^{\mathrm{b}}$ & $193.32^{\mathrm{a}}$ & $*$ & $199.70^{\mathrm{a}}$ & $154.75^{\mathrm{b}}$ & $* *$ & $199.70^{\mathrm{a}}$ & $166.38^{\mathrm{ab}}$ & $143.13^{\mathrm{b}}$ & $*$ & 8.26 \\
\hline Tearing $(\mathrm{kg} / \mathrm{cm})$ & 39.33 & 45.61 & NS & $51.05^{\mathrm{a}}$ & $38.18^{\mathrm{b}}$ & $* *$ & $51.05^{\mathrm{a}}$ & $41.58^{\mathrm{b}}$ & $34.78^{c}$ & $* *$ & 1.72 \\
\hline Elongation (\%) & 56.36 & 60.49 & NS & 57.13 & 59.07 & NS & 57.13 & 58.57 & 59.58 & NS & 1.52 \\
\hline Bursting (mm) & 9.68 & 9.57 & NS & 9.46 & 9.71 & NS & 9.46 & 9.97 & 9.46 & NS & 0.19 \\
\hline $\begin{array}{l}\text { PWV } \\
\left(\mathrm{mg} / \mathrm{mm}^{2} / \mathrm{hr}\right)^{1}\end{array}$ & $354.49^{b}$ & $424.17^{\mathrm{a}}$ & $*$ & 406.33 & 380.83 & NS & 406.33 & 379.50 & 382.16 & NS & 12.79 \\
\hline W. Abs-2hrs $(\%)^{2}$ & $235.13^{\mathrm{a}}$ & $190.48^{\mathrm{b}}$ & $* *$ & 194.68 & 221.87 & NS & 194.68 & 209.38 & 234.36 & NS & 7.13 \\
\hline W. Abs-24hrs (\%) & $271.86^{\mathrm{a}}$ & $219.10^{\mathrm{b}}$ & $* *$ & 238.39 & 249.03 & NS & 238.39 & 243.08 & 254.98 & NS & 8.16 \\
\hline \multicolumn{12}{|l|}{ Chemical properties } \\
\hline Fat $(\%)$ & 10.93 & 12.08 & NS & 11.86 & 11.33 & NS & 11.86 & 11.13 & 11.53 & NS & 0.35 \\
\hline Moisture (\%) & 14.00 & 14.77 & NS & 14.22 & 14.46 & NS & 14.22 & 14.29 & 14.64 & NS & 0.19 \\
\hline Ash $(\%)$ & 3.39 & 3.40 & NS & $8.49^{\mathrm{a}}$ & $0.85^{\mathrm{b}}$ & $* *$ & $8.49^{\mathrm{a}}$ & $0.86^{\mathrm{b}}$ & $0.84^{\mathrm{b}}$ & $* *$ & 0.68 \\
\hline $\mathrm{pH}$ & 3.28 & 3.45 & NS & $4.68^{\mathrm{a}}$ & $2.70^{\mathrm{b}}$ & $* *$ & $4.68^{\mathrm{a}}$ & $2.75^{\mathrm{b}}$ & $2.66^{\mathrm{b}}$ & $* *$ & 0.18 \\
\hline
\end{tabular}

$a, b$ and $c$ means in the same row with different superscripts were significantly different $(P<0.05)$.

$P W V=$ Permeability to water vapor.

$W$. Abs $=$ Water absorption $*$ Significant at $P<0.05 * *$ highly significant at $P<0.01$. NS: Not significant.

\section{Tanning method and material effects}

Although most physical properties of tanning method were insignificant differed, the mineral leathers were higher quality than vegetable leathers for their excellence in tensile $\left(199.70 \mathrm{~kg} / \mathrm{cm}^{2}\right)$ and tearing $(51.05$ $\mathrm{kg} / \mathrm{cm})$ values significantly $(\mathrm{P}<0.01)$. This trend was expected and in accordance with other investigators, who found the same trends in leathers produced from another animal species (Swamyet al., 1984; Gupta, 1986 and Stephens et al., 1989). Covington (2009) explained that chrome tanning depending on making short, rigid and non- labile cross-links with carboxyl groups in collagen fibers, while in vegetable tanning the crosslinks is weaker and more labile with amino groups in collagen fibers.

With respect to tanning material, chrome leathers were the highest quality because their significant superiority in tensile and tearing strengths. Quebracho leathers were lower in fullness than mimosa leathers because significant decrease in weight $(0.312 \mathrm{~kg})$ and thickness $(1.31 \mathrm{~mm})$ were shown.

On the other hand, quebracho leathers were higher quality than mimosa leathers because their increase in strengths values. This result is in agreement with Leach (1995) and BASF (2007), who explained that mimosa extract had excess amount of sugar than quebracho extract. The fermentation of sugar produces gallic acid and causes more swelling and increase in leather thickness. Thus, the negative relation between thickness and strengths as explained by Kotb (1978) and Abdelsalam et al. (1998) may be the reason for increasing quebracho leathers in quality than mimosa leathers.

Thus, results showed that using chromium in tanning was the best material followed by quebracho then mimosa extracts. 
Table (2): Least square means $\pm S E M$ of physical and chemical properties of tanned leathers as affected by interaction between breed, tanning method and tanning material.

\begin{tabular}{|c|c|c|c|c|c|c|c|c|c|c|c|c|c|}
\hline \multirow[t]{3}{*}{ Item } & \multicolumn{5}{|c|}{ Breed X Method } & \multicolumn{7}{|c|}{ Breed X Material } & \multirow[b]{3}{*}{ SEM } \\
\hline & \multicolumn{2}{|c|}{ Barki } & \multicolumn{2}{|c|}{ Abu-Dleek } & \multirow{2}{*}{ Sig. } & \multicolumn{3}{|c|}{ Barki } & \multicolumn{3}{|c|}{ Abu-Dleek } & \multirow[b]{2}{*}{ Sig. } & \\
\hline & Mineral & Vegetable & Mineral & Vegetable & & Chrome & Quebracho & Mimosa & Chrome & Quebracho & Mimosa & & \\
\hline $\mathrm{N}$ & 5 & 10 & 5 & 10 & -- & 5 & 5 & 5 & 5 & 5 & 5 & -- & \\
\hline \multicolumn{14}{|l|}{ Physical properties } \\
\hline Weight $(\mathrm{kg})$ & 0.268 & 0.325 & 0.289 & 0.360 & NS & $0.268^{\mathrm{b}}$ & $0.312^{\mathrm{b}}$ & $0.338^{\mathrm{ab}}$ & $0.289^{\mathrm{b}}$ & $0.312^{\mathrm{b}}$ & $0.408^{\mathrm{a}}$ & $*$ & 0.022 \\
\hline Thickness (mm) & $0.87^{\mathrm{c}}$ & $1.52^{\mathrm{a}}$ & $0.78^{\mathrm{c}}$ & $1.27^{\mathrm{b}}$ & $* *$ & $0.87^{\mathrm{c}}$ & $1.44^{\mathrm{ab}}$ & $1.60^{\mathrm{a}}$ & $0.78^{\mathrm{c}}$ & $1.18^{\mathrm{b}}$ & $1.36^{\mathrm{ab}}$ & $* *$ & 0.08 \\
\hline Tensile $\left(\mathrm{kg} / \mathrm{cm}^{2}\right)$ & $186.20^{\mathrm{a}}$ & $126.13^{\mathrm{b}}$ & $213.20^{\mathrm{a}}$ & $183.38^{\mathrm{a}}$ & $* *$ & $186.20^{\mathrm{a}}$ & $136.00^{\mathrm{bc}}$ & $116.25^{\mathrm{c}}$ & $213.20^{\mathrm{a}}$ & $196.76^{\mathrm{a}}$ & $170.00^{\mathrm{ab}}$ & $* *$ & 10.70 \\
\hline Tearing $(\mathrm{kg} / \mathrm{cm})$ & $50.30^{\mathrm{a}}$ & $33.85^{\mathrm{c}}$ & $51.80^{\mathrm{a}}$ & $42.51^{\mathrm{b}}$ & $* *$ & $50.30^{\mathrm{a}}$ & $34.90^{\mathrm{b}}$ & $32.79^{\mathrm{b}}$ & $51.80^{\mathrm{a}}$ & $48.26^{\mathrm{a}}$ & $36.76^{\mathrm{b}}$ & $* *$ & 2.37 \\
\hline Elongation (\%) & 58.45 & 55.32 & 55.80 & 62.83 & NS & 58.45 & 55.87 & 54.76 & 55.80 & 61.26 & 64.40 & NS & 2.66 \\
\hline Bursting (mm) & 9.37 & 9.84 & 9.54 & 9.58 & NS & 9.37 & 9.51 & 10.17 & 9.54 & 10.42 & 8.74 & NS & 0.27 \\
\hline $\mathrm{PWV}\left(\mathrm{mg} / \mathrm{mm}^{2} / \mathrm{hr}\right)$ & $373.65^{\mathrm{ab}}$ & $344.91^{\mathrm{b}}$ & $439.00^{\mathrm{a}}$ & $416.75^{\mathrm{ab}}$ & $*$ & 373.65 & 331.00 & 358.83 & 439.00 & 428.00 & 405.50 & NS & 19.22 \\
\hline Abs-2hrs (\%) & $196.15^{\mathrm{b}}$ & $254.61^{\mathrm{a}}$ & $193.20^{\mathrm{b}}$ & $189.13^{\mathrm{b}}$ & $* *$ & $196.15^{\mathrm{c}}$ & $230.50^{\mathrm{b}}$ & $278.73^{\mathrm{a}}$ & $193.20^{\mathrm{c}}$ & $188.25^{\mathrm{c}}$ & $190.00^{c}$ & $* *$ & 5.21 \\
\hline Abs-24hrs (\%) & $239.18^{\mathrm{b}}$ & $288.20^{\mathrm{a}}$ & $237.60^{\mathrm{b}}$ & $209.85^{\mathrm{b}}$ & $* *$ & $239.18^{\mathrm{bc}}$ & $262.65^{\mathrm{b}}$ & $313.75^{\mathrm{a}}$ & $237.60^{\mathrm{bc}}$ & $223.50^{\mathrm{cd}}$ & $196.20^{\mathrm{d}}$ & $* *$ & 8.43 \\
\hline \multicolumn{14}{|l|}{ Chemical properties } \\
\hline Fat $(\%)$ & 11.01 & 10.90 & 12.70 & 11.76 & NS & 11.01 & 10.13 & 11.66 & 12.70 & 12.13 & 11.40 & NS & 0.44 \\
\hline Moisture (\%) & 13.56 & 14.22 & 14.88 & 14.71 & NS & 13.56 & 14.01 & 14.42 & 14.88 & 14.56 & 14.86 & NS & 0.22 \\
\hline $\operatorname{Ash}(\%)$ & $8.34^{\mathrm{a}}$ & $0.92^{\mathrm{b}}$ & $8.64^{\mathrm{a}}$ & $0.78^{\mathrm{b}}$ & $* *$ & $8.34^{\mathrm{a}}$ & $0.84^{\mathrm{b}}$ & $1.00^{\mathrm{b}}$ & $8.64^{\mathrm{a}}$ & $0.88^{\mathrm{b}}$ & $0.69^{\mathrm{b}}$ & $* *$ & 1.01 \\
\hline $\mathrm{pH}$ & $4.63^{b}$ & $2.60^{\mathrm{b}}$ & $4.74^{\mathrm{a}}$ & $2.81^{\mathrm{b}}$ & $* *$ & $4.63^{\mathrm{a}}$ & $2.63^{\mathrm{b}}$ & $2.57^{\mathrm{b}}$ & $4.74^{\mathrm{a}}$ & $2.88^{\mathrm{b}}$ & $2.74^{\mathrm{b}}$ & $* *$ & 0.25 \\
\hline
\end{tabular}

$a, b, c$ and $d$ means in the same row with different superscripts were significantly different $(P<0.05)$.

$P W V=$ Permeability to water vapor,$W$. Abs $=$ Water absorption .

* Significant at $P<0.05$, ** Highly significant at $P<0.01$, NS: Not significant. 


\section{Interaction between breed and tanning method effect}

From obtained results shown in Table (2), the significant differences were found with most physical properties. Breed effect was not found within mineral tanning leathers, which were comparable in quality. But mineral leathers were higher than vegetable leathers because their significant increase in tensile and tearing strength values, and the significant decrease in thickness and water absorption values.

On the other hand in vegetable tanning method, Abu-Dleek leathers had higher quality than Barki leathers because their significantly differences in strengths, PWV, thickness and water absorption values. All these results were in accordance with those explained previously in breed, tanning method and material effects.

\section{Interaction between breed and tanning material effect:}

Quebracho leathers had quality higher than mimosa leathers and lower than chrome leathers. That is due to their weight, thickness, strengths and water absorption values, which were in average between those values obtained from other leathers.

Other interaction effect between breed and tanning material was similar in trends with interaction between breed and tanning method effect.

\section{Chemical properties}

Significant differences $(\mathrm{P}<0.01)$ were only observed between mineral and vegetable tanning leathers in ash and $\mathrm{pH}$ values (Table 1). Mineral tanned leather (chrome leather) had higher values of ash and $\mathrm{pH}$ than vegetable tanned leather (quebracho or mimosa leather). That due to chromium salts which added in chrome tanning method.

On the other side, higher $\mathrm{pH}$ values due to neutralization step in chrome tanning which done by adding alkaline. As for the interaction between breed and either tanning method or material in chemical properties (Table 2$)$, results showed significant effects $(\mathrm{P}<0.01)$ for ash and $\mathrm{pH}$ values. It seems that the effect of chrome tanning override the interaction influences.

Generally, when comparing all leather properties shown in Tables (1) and (2) which obtained from this study with BASF (2007). limitation range, it can be concluded that all sheep leathers from Barki and Abu-Dleek breeds can be used in wide different manufacturing uses; e.g. clothing, gloves, chamois, lining, upholstery, and shoe upper leathers.

\section{CONCLUSION}

Despite of Abu-Dleek leathers had higher quality than Barki leathers, both of them can be utilized in different manufacturing uses such as garment, lining, upholstery and shoe upper. In addition, the attention in live sheep caring, slaughtering, preserving and collecting sheep skins in desert areas will maximize the benefits instead of current situation in Egypt.

On the other hand, mineral tanning with chrome is considered the most common tanning method in Egypt for decreasing production cost and increasing their leather quality but the vegetable tanning method is still the better in the world for decreasing negative environmental impact for leather tanning.

\section{ACKNOWLEDGMENT}

Authors would like to thank Mr Hassan Kalash, proprietor of Kalash tannery, Alexandria, Egypt for his help and support in the practical part.

\section{REFERENCES}

Abdelsalam, M.M. and Haider, A.I. (1993).Physical and histological properties of sheep and goat skins. Alexandria J. Agric. Res., 38: 117-124.

Abdelsalam, M.M., El-Gabbas, H.M. and Abdelaziz, N.M.(1998). Physical properties of raw hides and leather of the Egyptian camel. Alex. J. Agric. Res. 43, 13-19.

Anthony, D. (1998). New tannages for the new millennium. J. American Leather Chemists Asso, 93 : 168-182. 


\section{Nasr et al.}

Azzam, A.H. (2003). Application of some untraditional methods for skin preservation in some desert areas. J. Agric. Sci. Mansoura Univ., 28 (7): 5215-5223.

BASF (2007).Pocket Book for leather Technologist. $4^{\text {th }}$ ed, 67056 Ludwigshafen, Germany.

Chakir, A. (2001). Adsorption of trivalent chromium from aqueous solutions onto expanded perlite. International J. of Environmental Studies, Vol. 4. ISSN 1097-7104.

Covington, A. D. (2009). Tanning chemistry the science of leather. RSC publishing, Cambrige, London.

Egyptian Standards (E.S.122) (2005).Methods of sampling and physical testing of leather.

Egyptian Standards (E.S.123) (2001).Methods of sampling and chemical testing of leather.

FAO (2013).Statistical Yearbook. World Food and Agriculture, Rome.

Gupta, S.D.(1986). Innovations in tanning processes. Leather Sci. 33, 33-45.

Jackson-Mass, C. A. and Snyman, M. A. (2000). A comparison of the leather produced from the skins of ten different South Africa sheep breeds. South African J. Animal Sci., 30: 129 -130.

Kotb, A.A. (1987). Studies on physical and histological properties of hides and skins of farm animals. M.Sc. Thesis, Faculty of Agric., Alex. Univ., Egypt.

Leach, I. (1995). Hides and skins for the tanning industry. FAO Agriculture development paper, Rome.

Nasr, A.I. (2011). Using some plants and their crude extracts in leather tanning. Ph.D. Thesis, Faculty of Agric., Alex. Univ., Egypt.

SAS (2008). User's guide: Statistics. Version 9.2 edition. SAS Institute Inc., Cary, NC.

Stephens, L.J., Peters, D.E. and Trajstman, A.C. (1989). The physical properties of leather from Kangaroo skins III. Comparison between sirolime and conventional unhairing and between chrome and vegetable tanning. JALCA., 84: 296-305.

Swamy, M.P., Bangaruswamy, S., Chatterjea, J.N. and Rao, J.B. (1984). Studies on straight and combination tanned leathers with titanium, chrome, aluminium, vegetable and syntan - Part VI. Leather Sci. 31, 195-206.

Younis, A.A. (1995). Improving performance of Barki sheep through selection and crossing with other breeds. A Workshop on the Development of Animal Production in the Desert and Newly Reclaimed Areas, 1-6.

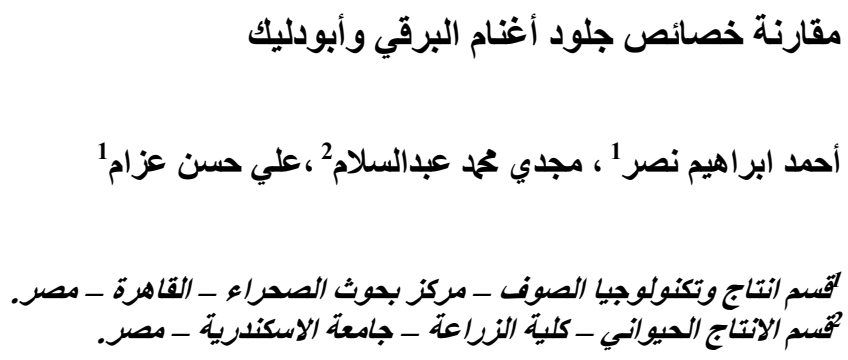

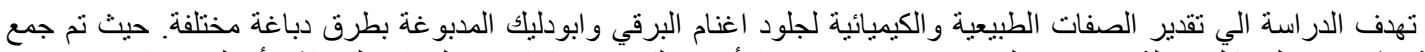

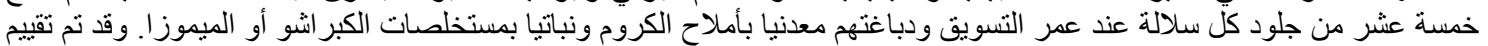

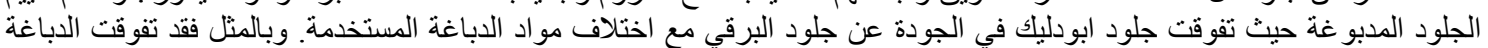

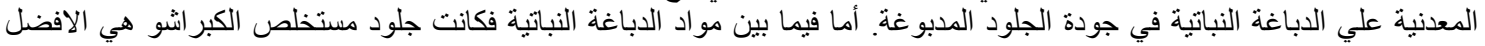

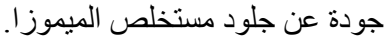

